\title{
Examining the effectiveness of micro- enterprise development programs in Malaysia
}

\author{
Noor Raihani Zainol \\ Universiti Malaysia Kelantan, \\ Kota Bharu, Malaysia \\ Email:raibani@umk.edu.my
}

\author{
Abdullah Al Mamun \\ Global Entrepreneurship Research and Innovation Centre (GERIC), \\ Kota Bharu, Universiti Malaysia Kelantan \\ Email:abdullah.a@umk.edu.my
}

Hasannuddin Hassan

Universiti Malaysia Kelantan, Kota Bharu, Malaysia

Email:hasann@umk.edu.my

\author{
Rajennd A/L Muniady \\ Universiti Malaysia Kelantan, \\ Kota Bharu, Malaysia \\ Email: rajennd_57@yahoo.com
}

Abstract. Previous studies on socioeconomic development have examined the effect of development initiatives (i.e., access to finance and training) on several socioeconomic indicators (i.e., income, empowerment, asset, quality of life, employment). These studies have focused mostly on the outcomes of specific types of programs offered by specific development organizations. This study however focuses on informal women micro-entrepreneurs' participation in various development programs available to them and their influence on entrepreneurial competencies, human capital development, competitive advantages, economic vulnerability, supportive environment, and performance of micro-enterprises. This cross-sectional study adopted the purposive random sampling method and collected data from 384 informal women entrepreneurs from the local markets in different districts of Kelantan, Malaysia. The findings show that the development program participants have relatively higher levels of entrepreneurial competencies, human capital development, and higher levels of enterprise performance compared to non-participants. It is also noted that the level of economic vulnerability is relatively low among participants compared to non-participants. However, these findings contradict most of the earlier studies

Received: October, 2016 1st Revision: March, 2017 Accepted: May, 2017

DOI:

10.14254/2071$8330.2017 / 10-2 / 20$ 
that show a significant positive impact of micro-credit on socio-economic wellbeing, as the difference in entrepreneurial competencies, human capital development, economic vulnerability, and performance of micro-enterprises among participants and non-participants in this study is not statistically significant. However, findings reported significantly higher levels of competitive advantages, and better supportive environment among the participants compared to the non-participants. Development organizations should therefore focus on expanding their outreach to spread the positive effects of their development programs towards uplifting the economic condition of low and middle-income households in Malaysia.

Keywords: effectiveness, development initiatives, informal micro-enterprises.

JEL Classification: O12

\section{INTRODUCTION}

The informal sector is considered to be a significant element of the economy, especially in the developing parts of the world. It is also known as unregistered and/or non-officially recorded activities by law (Mapp \& Moore, 2015). Activities of individuals engaged in the informal sectors should not always be classified as illegal. This is because it is their choice not to formalize their business (Mapp \& Moore, 2015). As they are neither registered, nor formalized, recording of data and information of the informal sector is almost impossible (Habibullah \& Eng, 2006). However, it is still important to monitor and consider the informal economy and its activities, as it creates employment and contributes to the economy, especially in developing countries.

Consequently, the Ministry of Human Resource Malaysia (MOHR) has identified the factors that cause the existence of informal sectors in Malaysia. There are four factors, which include: 1) Lack of awareness and knowledge of the rules, regulations, and advantages of registering a business; 2) Business factors, such as the high cost of registration, are considered not effective by informal entrepreneurs; 3) Regulatory issues including the intention to evade taxes, bureaucratic challenges (procedures of registration), and lack of enforcement and action (authority); and 4) Environmental barriers such as remote location of businesses (owned or operated by non-citizens) (Kuchairi \& Nur Layali, 2015). The report also mentions that there are four groups of informal micro-enterprises, namely, wholly permanent with no intention to formalize, wholly temporary with the intention to formalize, partially permanent with no intention to formalize at least in the foreseeable future, and partially temporary with the intention to formalize. According to Hafizah et al., (2011), informal micro-enterprises have a significant role in the Malaysian economy since they contribute to the gross domestic product of the country, are active in generating income, employment and community development, and also act as a platform to enhance the entrepreneurs' skills before moving into the formal sector.

Earlier studies have illustrated the contributions of informal entrepreneurship towards the economy through the provision of employment, production, income generation, supplying ignored markets, and poverty alleviation (Monroe, Allen \& Price, 1996). Mlinga and Wells (2002) claim that this sector supplies low and middle-income employees of the formal sector with products and services not offered by the formal sector. As such, an informal micro-enterprise is a particularly important source of employment and income for women (Lloyd-Evans, 2008), as well as a way to achieve sustainable livelihood (Spevaek, 2011). Pages (2005) and Sharma, Sapna, and Hatwal, (2012) agree that women owning informal micro-enterprises have become important players in the entrepreneurial landscape. Numerous researchers have supported Pages' 
study, since in many Southeast Asian countries, hawking represents an important informal microentrepreneurial activity for women (Bhowmik, 2005; Nirathron, 2006). This is due to poverty and the fact that male members of the families often do not have permanent jobs (Bhowmik, 2005). Women are involved in informal economy as street vendors, hawkers, petty traders, housemaids, night market operators, and other self-employed daily-waged activities (Williams \& Windebank, 2006). Hence, households depend on women's informal activities as a means of survival (Hafizah et al., 2011).

The informal sector is often described as a safety net during economic downturns for the people retrenched from formal employment. In times of economic crisis, individuals who lose their jobs become new entrants and join the informal economy. Furthermore, women's informal micro-enterprises also face formal economic vulnerability issues even though they belong to the informal sector (Bertulfo, 2011). Informal economic activities are not subjected to official scrutiny and regulations including laws regulating taxes, environmental protection, safety in the workplace, and labor contracts. Lack of protection entails a higher vulnerability, especially when people are exposed to risks related to physical safety and health (Bertulfo, 2011), and higher stress levels (Sverke, Hellgren, \& Nasvall, 2006). They also do not receive overtime payments, a minimum wage, paid vacation and sick leave, health insurance, work hazards management, unemployment insurance, and maternity benefits (Bertulfo, 2011). Meanwhile, Kweka and Fox (2011) noted that in urban areas, informal micro-enterprises face one of the biggest constraints, which is the lack of access to a suitable workspace to conduct business. The same study also identified other factors of vulnerability faced by the informal economy players such as serious illness, death, and wedding in the family. This forces them to raise money by borrowing or drawing from their already limited savings. In some scenarios, vulnerability for informal micro-enterprises is in the forms of poverty, low skill development, low level of productivity, lack of product development and marketing know-hows, poor hygiene and sanitary practices, outdated processing methodology and equipment, limited access to loans, and low access to markets (Hicks, 2012).

On the other hand, previous researchers have identified that training (Putnam, 1993), access to financing such as loans (Servon \& Doshna, 2000), and business support services (Abdullah \& Manan, 2010) are critical success factors for small businesses (Schmidt \& Kolodinsky, 2007). Vulnerability can be defined as the probability that individuals, households, or communities will be in poverty in the future, which can translate into long-term poverty. The explanation above provides a theoretical link between vulnerability, entrepreneurial competencies or activities, and performance of women's informal micro-enterprises. Borron and Murray (2004) believe that addressing the conditions of female informal workers would contribute to poverty reduction and improve the lives of at least half of the working population in many countries. When living and working conditions of female informal workers improve, so does their productivity, which leads to increased income, contributes to overall economic growth, effectiveness, and reduces poverty in the long term. This study therefore focuses on examining the effects of various development programs on entrepreneurial competencies, human capital development, competitive advantages, economic vulnerability, supportive environment, and performance of micro-enterprises among the informal women microentrepreneurs in Kelantan, Malaysia.

\section{LITERATURE REVIEW}

The review starts with the description of products and services offered by selected leading development organizations in Malaysia, followed by the association between participation in development organizations and its effect on entrepreneurial competencies, human capital development, supportive environment, 
competitive advantage, and the performance of micro-enterprises owned and managed by women informal micro-entrepreneurs in Kelantan, Malaysia.

\section{Micro-enterprise development programs in Malaysia}

In order to improve the socio-economic condition of low-income and poor households in Malaysia, the government and non-government organizations have designed various policies and programs, which offer many types of loans, training, advisory services, and platform for promoting entrepreneurial activities. Below are the list of selected key development organizations in Malaysia and the product and services they offer to low-income and poor households in order to improve their socio-economic conditions.

Amanah Ikbtiar Malaysia (AIM) is a major microcredit institution in Malaysia, which aims to eradicate poverty among low-income households by providing group-based microcredit to support incomegenerating activities to women. To achieve this, AIM offers seven micro-credit schemes, which are $i-M e s r a$, $i$-Srikandi, $i$-Wibawa, $i$-Sejabtera, $i$-Bestari, i-Penyayang, and $i$-Emas. The limit of loan amount ranges from RM1, 000 to RM10, 000 and the repayment period is from 12 weeks to 150 weeks. The procedures of the AIM are: a group should consist of 5 members, follow the process to comprehend the rules and terms of AIM, and attend weekly meetings at designated centers. The qualification for the loan is that the applicants must be Bumiputera and their household income should range between RM838 and RM3, 855 per capita.

The National Savings Bank (BSN) actively helps micro-entrepreneurs to expand their businesses via the Micro Finance Scheme and has successfully groomed 18,000 of their customers to the next level. Their micro finance is divided into two schemes, which are (1) BSN Micro (conventional) consisting of TemaNiaga and TamanMesra, and (2) BSN Micro-I (islamic) including TemaNiaga-i Murabahah, and TemaNiaga-I Tawarruq.

The Department of Social Welfare (JKM) aims to develop a prosperous and caring society with the motto "Service with dedication". There are four branches in the community department such as Volunteer, Welfare Volunteer Association, Community, and Multi-sector. In the community division, JKM offers programs that help entrepreneurs to expand their business and encourages social development activities through urban transformation centers.

The KEMUBU Agricultural Development Authority (KADA), which comes under the Ministry of Agriculture and Agro-Based Industry Malaysia, provides quality, efficient and effective services in the areas of water supply resources, irrigation and drainage management systems, and agricultural applications technology through an integrated development approach towards the increase in rice crop productivity and other food products, and increases the socio-economic standards of farmers and entrepreneurs. These farmers and entrepreneurs gain guidance and aid from KADA in the form of advisory services and/or financial aids, to help them expand their businesses.

The Council of Trust for the Bumiputera (MARA) is a division under the Ministry of Rural and Regional Development that works towards developing, facilitating, and fostering economic and social development. The entrepreneurship division consists of the entrepreneurship sector, entrepreneur development, industrial and infrastructure development, business financing, business premises, and landscapes. MARA is focused on entrepreneur development through entrepreneur training, business consultation services, marketing development, and technopreneur development.

The National Entrepreneurial Group Economic Fund (TEKUN) is an agency under the Ministry of Entrepreneurial and Cooperative Development, which provides micro financing and support services towards entrepreneurial development. Moreover, another platform provided for entrepreneurs is the TEKUN Entrepreneur, which is divided into several programs, namely TEKUN National Financing Scheme, Teman Tekun Financing Scheme, Temannita Financing Scheme, Kontrak-I Financing Scheme, Ar- 
Rahnu Tekun, Indian Community Entrepreneur Development Scheme (SPUMI), Special Programs, TEKUN Entrepreneur Community Club, TEKUN National, and Entrepreneurship Institute.

\section{Entrepreneurial Competencies}

Entrepreneurial competencies play a vital role in ensuring success and sustainability of a business (Hee \& Daisy, 2013). Previous studies agree that it is important for entrepreneurs to have certain strategic skills or competencies for optimum functioning such as organizational capabilities, efficiency orientation, planning, persuasiveness, self-confidence, organizational awareness, directing, teamwork, leadership, and benchmarking that have an impact on firm performance (Man, Lau, \& Chan, 2000; Kaur \& Bains, 2013), as well as being strong predictors of business success (Ahmad, Halim \& Zainal, 2010). This is important to remain competitive in the global market (Shenura, Haile, \& Negash, 2016). By having entrepreneurial competencies, an entrepreneur has an advantage in planning, cultural awareness, decision-making, and solving problems that contribute to business development (Nurach \& Chandrachai, 2012). There are many studies regarding entrepreneurial competencies, which define and identify different dimensions of entrepreneurial competencies. For example, Camuffo, Gerli, and Gubitta (2012) focused on threshold and distinctive competencies; management competencies (Parast \& Adam, 2012); functional competencies; and interpersonal competencies (Sambasivan, Lim, Rose, \& Abdul, 2010). This study, therefore, focuses on six key areas of entrepreneurial competency as provided by Man and Lau (2000), which include opportunity recognition competency, relationship competency, conceptual competency, organizing competency, strategic competency, and commitment competency.

The most important ability of a successful entrepreneur is his/her ability to recognize incomegenerating opportunities (Man \& Lau, 2000). At the same time, 'opportunity recognition' helps to identify customers' unmet needs and wants (Shenura, Haile, \& Negash, 2016). This makes it possible for entrepreneurs to discover new methods, solutions, and the ability to analyze in order to avoid taking risky decisions that might lead to business failure (Skrzeszewski, 2006). Opportunity recognition competency ultimately adds value to the entrepreneur and improves decision-making (Jawahar \& Nigama, 2011; Hunter, 2011). The next competency discussed here is "relationship competencies". This competency involves person-to-person-based interactions or individual-to-group-based interactions related to the context of building and improving co-operation, trust, connections, persuasive ability, communication, and interpersonal skills (Man \& Lau, 2000). Kaur and Bains (2013) in their study explain that a successful relationship competency is based on how the entrepreneurs put to use good interpersonal and communication skills, their ability to influence others, and gain support. This competency to build and maintain strong relationships gives the entrepreneurs a strong and good relation with their suppliers to gain benefits such as favorable credit terms, discounts, or affordable prices for raw material. Consequently, it leads to continuous relationship and creation of goodwill in the business because trust has been established among the stakeholders, including their customers (Man \& Lau, 2000). According to Man and Lau (2000), conceptual competencies are reflected in the behavior of the entrepreneurs, such as making decisions immediately about market opportunities or absorbing and understanding complex information for enterprise improvement. These entrepreneurs can view the market environment or operations of the business from a different perspective and find an alternative way to solve problems. However, this concept is associated with risk; the condition of risk is assessed through a new market with different ways of sourcing and building new capabilities (Man \& Lau, 2000; Kraus, Rigtering, Hughes, \& Hosman, 2012). This relates to the entrepreneurial requirement for analytical competency when the entrepreneur has to address complex situations (Eyre \& Smallman, 1998; Man \& Lau, 2000). 
The next competency is 'organizing competencies'; it includes the different internal and external human, physical, financial, and technological resources, team-building, managing employees, training, and controlling for business performance (Man \& Lau, 2000; Bae \& Rowley, 2004). Thus, to operate a business successfully, entrepreneurs should have the ability to lead, command, coordinate, control, manage, monitor, delegate, motivate, and organize internal and external resources of the business such as budget preparation, materials, human resources, plan and schedule work, and develop programs (Snell \& Lau, 1994; Man et al., 2002; Kaur \& Bains, 2013). Accordingly, entrepreneurs should be specialized in taking responsibility for and making wise decisions that will affect the situation, location, environment, form, materials, resources, goods, or building (Hebert \& Link, 1989; Zahra \& Nambisan, 2012). However, Hussain and Zafar (2010) believe that organizing competencies refer to how the entrepreneurs organize their businesses, as well as themselves and their skills to identify the talents that can be developed. The next competency is 'strategic competencies', which is related to the entrepreneurs' ability to develop a vision in mind for their business (Snell \& Lau, 1994; Thompson, Stuart, \& Lindsay, 1996). Thus, to develop the vision for business strategy, an entrepreneur should focus on formulating and implementing strategies, planning, setting clear goals and standards, forecasting financial, as well as thinking and creating ideas (Kaur \& Bains, 2013; Man \& Lau, 2000) in order to influence customers or competitors in the market (Parkman, Holloway, \& Sebastiao, 2012). As noted by Becker, Huselid, \& Ulrich (2001) and Brush and Ruse (2005), a business vision and mission allows entrepreneurs to plan long-range goals and objectives which provides them with a solid framework to identify the needed resources in the form of equipment, capital, and personnel that makes a business more adaptive and responsive to the demands of the business environment. Finally, commitment competencies refer to the drive for an entrepreneur to move ahead in his/her business to achieve long-term goals with strong motivation (Man \& Lau, 2000), take initiatives (McClelland, 1987), and possess entrepreneurial attitude (Schaltegger, Ludeke-Freud, \& Hansen, 2012; Achtenhagen, Melin, \& Naldi, 2013). Wells, Pfantz, and Bryne (2003) find that entrepreneurs who have adequate inner quality will put in strong effort and hard work to achieve their goals. At the same time, engaging one's ambition and being determined requires total commitment from entrepreneurs in order to manage their business successfully (Sambasivan, Lim, Rose, \& Abdul, 2010). Entrepreneurs with a high level of commitment competency make large personal sacrifices, such as working long hours, maintaining a high energy level and motivating their self to function at an optimum level of performance to ensure that they are satisfied with their own work (Chandler \& Jansen, 1992; Kozan, Oksoy, \& Ozsoy, 2012).

\section{Human Capital Development}

Human capital is a term coined in the 1960s by an American economist, Theodore Shultz, which Gary Becker, later on, converted into a theory. According to the human capital theory, investments in education and job skills (training) are a part of an individual's capital (Xiao, 2002), future earnings potential, and an important input to economic growth and development (Siqueira, 2007). Accordingly, researchers such as Ployhart, Weekley, and Baughman (2006) further expand on the theory by including knowledge, skills, abilities, and other competencies that are important to an organization's employee. As a result, this has increased an individual's cognitive capacity including productivity, as well as an individual's earnings, which has ultimately become a measure of human capital (Olssen, Codd, \& O'Neill, 2004). However, researchers are still focused on validating the human capital theory by focusing on measuring the increased incomeearning potential at the individual, community, and national levels (Lehrer, 2004; Gibbs, 2005; Seo, 2005). Gibbs (2005) recommends that the educational level of a community area has the ability to attract new businesses to any geographic area with three benefits. Firstly, it assists local businesses in adopting new 
technologies to respond more quickly towards changing economic situations. Secondly, human capital enhances and facilitates small and medium business ownership, as well as entrepreneurship with skilled workers including managers, financial advisors, technical experts, and others. Thirdly, high levels of human capital are also associated with substantial positive externalities, especially community, businesses, individuals, and contribute to job creation, through information exchange and networking among professionals that lead to creativity, new ideas, and new business opportunities. In addition, prior research suggests that human capital leads to a sustained competitive advantage (Carmeli \& Tishler, 2004; Hitt et al., 2006) and survival (Dencker et al., 2009) due to valuable, unique, and rare components of the human capital (Snell, 1999).

\section{Supportive Environment}

Positive and conducive environment is an important factor in the success of an informal economy of a country (Donatus, 2010). Typically, economic environment influences entrepreneurship, whether it is supportive or otherwise (Cooper, 1993). According to Donatus (2010), a supportive environment refers to a combination of factors in the environment that plays a role in the development or nurturing of entrepreneurship and entrepreneurial activities, such as the availability of financial resources, strategic location, training, and research. As noted by Bull and Willard (1993), a supportive environment includes conditions that provide security and support to a new endeavor or reduces discomfort from a previous one. Furthermore, supportive environmental factors are considered a reasonable starting point for the analysis of entrepreneurship (Covin \& Slevin, 1991). According to Tuyon, Bujang and Jidwin (2012), the way of strengthening the informal micro-enterprise is by improving its access to enterprise support services through various government and semi-government agencies and collaboration with state agencies and universities, in preparing business plans, loans, and business assistance. Generally, informal entrepreneurs lack choice and have less financial resources. Therefore, a major and important part that needs to be considered in informal micro-enterprise development is entrepreneurial finance and strategy for wise decision-making and knowledge sharing (Jawahar \& Nigama, 2011). According to UNDP (2014), women entrepreneurs have difficulties in getting loans from formal banks and the banks' regulations are considered a burden especially for women borrowers. However, development initiatives in managing an entrepreneur's support system have increased in Malaysia; this is true for informal micro-enterprises such as hawkers or night market sellers with the offering of financial support and training. Moving in that direction, the Malaysian government has provided several support programs and organizations such as Tabung Ekonomi Kumpulan Usaha Niaga (TEKUN), Pelan Insuran 1Malaysia Penjaja dan Peniaga Kecil Nasional (P1MPIN), Malaysian Agricultural Research and Development Institute (MARDI), and Federal Agricultural Marketing Authority (FAMA).

\section{Competitive Advantage}

Competitive advantage is important to small businesses such as micro-enterprises to improve the performance of their business by providing better products and services to their customers (D'Aveni, Dagnino, \& Smith, 2010). Lately, the concept of innovations is bringing changes to the internal environment, as well as changes to the external environment, which has resulted in ideas that entrepreneurs strive to gain a competitive advantage and distinguish their products and services from the competitors. A business with resources that are different from and superior to those of its competitors has the ability to generate the economy (Helfat \& Peteraf, 2015) and give the business a competitive advantage (Simsek \& Heavey, 2011; Sullivan \& Marvel, 2011). Researchers such as Bierly and Chakrabarti (1996) and Zack (1999) have provided guidelines for developing intellectual capital and creating competitive advantages through 
knowledge creation consisting of tangible and intangible knowledge, experience, and skills for entrepreneurs. Knowledge creation allows entrepreneurs to generate new innovative ideas based on inimitable skills and abilities that assist the micro-enterprise to achieve a competitive advantage (Moriah, 2010). In a study by Tidd et al. (2006), the researchers focused on the important characteristics of innovation that contribute to competitive advantage including a strong relationship between market performance and new products that help to maintain market shares and continue to generate profit. In achieving a higher competitiveness, one has to produce significantly less costly products of better quality compared to their competitors (Hana, 2013). Due to the highly competitive environment of the business world, the goal of an informal micro-enterprise is to defeat competition and fulfill needs and wants of the customer (Moriah, 2010), and outperform competitors as mentioned by Porter (1985). There are various studies that support the idea of innovation as a business competitive advantage enabler, for example, technological innovations and competitive advantage (Martín-de Castro et al., 2013), development and introduction of innovations (Zemplinerová, 2010), regional innovation (Noruzy et. al., 2012; Autant-Bernard, Fadairo, \& Massard, 2013), and capability of innovation (Martín-de et. al., 2013; Noruzy et. al., 2012).

\section{Economic Vulnerability}

According to Fussel (2007), vulnerability is a function of sensitivity and resilience. Sensitivity refers to the degree to which a system is instantly affected by perturbation, while resilience is the ability of the system to maintain its basic functions and return to the original state after a perturbation. On the other hand, vulnerability is considered the risk of being harmed and wounded, and negatively affected by unforeseen events (shocks) whether in general or in economics. For example, landlockedness, farness from a large market, and low levels of human resources tend to be serious handicaps to growth, but are not elements of vulnerability because they are not unforeseen events, however they may influence the consequences of a given shock (Vial \& Hanoteau, 2015). The researcher furthered the study and provided two main reasons for households to get involved in a micro-enterprise, which are to increase their income and consumption, in order to cope with economic vulnerability (Floro \& Swain, 2013; Verrest, 2013). This reason enables a micro-enterprise to diversify a family's sources of income, and boost it for the purpose of saving as mentioned by Verrest (2013). Moser (1998) believes that a poor household is more vulnerable compared to an entrepreneurial household, as it possesses fewer assets. The poor households are more exposed to certain risks (Sparrow et al., 2014), have lower access to formal insurance mechanisms such as insurance, credit, and social protection systems. Specifically, the informal micro-enterprise reduces vulnerability by diversifying the professional activities in the business and permitting higher savings (Vial \& Hanoteau, 2015). Current research supports the notion that micro-entrepreneurs who are involved in a night market or a hawker business have a strong tendency towards financial saving, which is consistent with the literature that they have low access to financial resources, and high exposure and vulnerability to risks (Vial \& Hanoteau, 2015). Assets accumulation represents a long-term insurance of welfare as added value compared to employment, especially for the informal micro-entrepreneurs. They have incentives to increase savings for lending, potential investment, and secure physical capital necessary to develop the business (Gentry \& Hubbard, 2004; Tipple, 2005; Vial \& Hanoteau, 2015). Therefore, micro-entrepreneurs assist in increasing the economic welfare as their trade-off objectives by providing livelihood for raising the living standards and addressing economic vulnerability (Verrest, 2013). 


\section{Micro-Enterprise Performance}

In relation to this, the definition of business performance could vary from one researcher to another. Interestingly, Rosa, Carter and Hamilton (1996) outlined four different measures of a micro-enterprise, namely, a) primary performance measures including the number of employees, growth in employees, sales turnover, and value of capital assets; b) proxy performance measures, such as geographical range of markets; c) subjective measures, including the ability of the business to meet business and domestic needs; and d) entrepreneurial performance measures of the desire for growth and the ownership of multiple businesses. Furthermore, Mead and Liedholm (1998) considered three measures of performance in their study including changes in the number of employees, profitability, and contribution to household income, which were used to measure micro-enterprise performance. Performances can be influenced by many factors, but some scholars agree that the measure of performance should be from their success or growth, profitability, and the relative performance (Chandler \& Jansen, 1992; Man et al., 2002). On the other hand, Simpson, Padmore, and Newman (2012) stated that the concept of performance has a high relation with the success of the entrepreneur, and this is one of the elements of performance. In the present study, following Islamic teachings according to the Qur'an and Hadith, an entrepreneur who strictly follows the rules and principles of the religion in running a business is regarded as a successful person in the present world and the hereafter (Mahmood \& Rosli, 2013). Okurut (2008) proposes that education level, experience, and business assets significantly influence the returns in micro-enterprises, which is crucial in enhancing the performance of women micro-enterprises. Furthermore, micro-enterprise performance depends not only on returns on firm-specific strategies but also on the cost of implementing these strategies, unique resource combinations, and competences of the enterprise (Barney, 1991; Lockett \& Thompson, 2001; Hawawini, Subramaniam \& Verdin, 2003). The success of a micro-enterprise is dependent on the decisions and actions of the entrepreneur with respect to products, production processes, human resources, marketing, and finance. The growth of micro-enterprises can be measured from three perspectives based on employment growth (Mead \& Liedholm 1998), revenue growth, and profit growth (McPherson, 1996; Fairlie \& Robb, 2009).

\section{RESEARCH METHODOLOGY}

This study adopted a cross-sectional research design and collected quantitative data through structured interviews with women with informal micro-enterprises who were involved in 'night markets' in Kelantan, Malaysia. The population has a number of collections of elements, through which conclusions can be drawn (Zikmund, 2003). The informal women entrepreneurs were selected from eight districts in Kelantan, Malaysia, which are Kota Bharu, Tanah Merah, Pasir Puteh, Tumpat, Machang and Ketereh. These women microenterprises are not registered with the Companies Commission of Malaysia (Suruhanjaya Syarikat Malaysia), as they do not have permanent business premises and location. Moreover, a complete list of informal microentrepreneurs is not available anywhere. This study therefore selected eight locations in Kelantan based on the size of the gathering of informal micro-entrepreneurs in the night markets. The informal microenterprises are registered with the local municipal council under different districts in Kelantan, whereby, they bear the cost of RM20 - RM36 per year for the payment depending on their respective District Council, referring to their business location in the night markets. This study then adopted the purposive random sampling method to select the informal women entrepreneurs from the local market in the different districts, who were expected to represent the informal women entrepreneurs in Kelantan, Malaysia.

A questionnaire was designed using simple and unbiased wordings so that the respondents could easily understand the questions and provide answers based on their own perception. Questions were adopted from earlier studies with minor modifications where needed. The details of each section, what it measures, 
and from which study the questions are adopted, are presented below. A five-point Likert scale ranging from 1 (strongly disagree) to 5 (strongly agree) was used; and a scale ranging from 1 (low) to 5 (very good) was used to measure the section on performance of the informal women enterprise.

\section{SUMMARY OF FINDINGS}

As presented in Table 1, there are 99 people in the first category of 20 to 30 years old at $25.8 \%$. This is followed by the second category of 31-40 years old where there are 107 people at $27.9 \%$. The third is 41 to 50 years old category with 108 people, making it the largest age group of the respondents with $28.1 \%$. 62 people are in the fourth category of 51 to 60 years old at 16.3\%, and for the fifth category of 61 years old and above, there are 7 people with a percentage of $1.8 \%$. Informal women entrepreneurs in Kelantan are mostly from the Malay ethnicity. 377 out of 384 of the sampled respondents are from the Malay ethnicity with $98.2 \%$, followed by 6 people from the Chinese ethnicity with a percentage of $1.6 \%$, and the third category only has one Indian person at $0.3 \%$. In the marital status category, 45 of the informal women entrepreneurs are still single and the percentage is $11.7 \%$. The largest number of 296 informal women entrepreneurs is married at $77.1 \%$ and lastly, $11.3 \%$ of them or 43 informal women entrepreneurs are single mothers. There are five categories for monthly income. The first category of the informal entrepreneurs' monthly income is at below RM1000. There are 36 people with $9.4 \%$ in this category. Second is the RM1001 RM2000 category with 183 people at 47.7\% and represents the highest frequency. The amount of RM2001RM3000 shows 127 people at 33.1\%. This is followed by RM3001-RM4000 category with 25 people at 6.5\%. Moreover, the last category is 13 people at $3.4 \%$. A total of 125 informal micro-entrepreneurs reported that they have been operating for 1 to 5 years, 126 entrepreneurs have been operating for 6 to 10 years, 75 entrepreneurs have been operating for 11 to 15 years, 36 respondents have been operating for 16 to 20 years and 21 entrepreneurs have been operating for more than 20 years.

Table 1

Respondents Details

\begin{tabular}{|c|c|c|c|c|c|}
\hline & $\mathbf{n}$ & $\%$ & & $\mathbf{n}$ & $\%$ \\
\hline Age & & & Ethnicity & & \\
\hline $20-30$ years old & 99 & 25.8 & Malay & 377 & 98.2 \\
\hline $31-40$ years old & 107 & 27.9 & Chinese & 6 & 1.6 \\
\hline $41-50$ years old & 108 & 28.1 & Indian & 1 & 0.3 \\
\hline $51-60$ years old & 62 & 16.5 & Others & 0 & 0 \\
\hline 61 years old and above & 7 & 1.8 & Total & 384 & 100.0 \\
\hline \multirow[t]{2}{*}{ Total } & 384 & 100.0 & & & \\
\hline & & & Marital Status & & \\
\hline Years in Business & & & Single & 45 & 11.7 \\
\hline $1-5$ years & 125 & 32.6 & Married & 296 & 77.1 \\
\hline $6-10$ years & 126 & 32.8 & Single mother & 43 & 11.2 \\
\hline $11-15$ years & 76 & 19.8 & & & \\
\hline $16-20$ years & 36 & 9.4 & Monthly Income & & \\
\hline $21-25$ years & 16 & 4.2 & Below RM1000 & 36 & 9.4 \\
\hline 26 years and above & 5 & 1.3 & RM1001-RM2000 & 283 & 47.7 \\
\hline \multirow[t]{4}{*}{ Total } & 384 & 100.0 & RM2001-RM3000 & 127 & 33.1 \\
\hline & & & RM3001-RM4000 & 25 & 6.5 \\
\hline & & & RM4001 and above & 13 & 3.4 \\
\hline & & & Total & 384 & 100.0 \\
\hline
\end{tabular}




\section{Participation in Development Programs}

As for participation in the development programs, out of the 384 respondents, 125 or $32.6 \%$ of the women informal micro-entrepreneurs are participating in various development programs offered by various development organizations in Malaysia, i.e., 80 out of 125 entrepreneurs are members of Amanah Ikhtiar Malaysia, 3 entrepreneurs are members of BSN (Bank Simpanan Nasional - National Saving Bank), 5 entrepreneurs are members of JKM (Jabatan Kebajikan Masyarakat - Department of Social Welfare), 12 entrepreneurs are members of KADA (Lembaga Kemajuan Pertanian Kemubu - KEMUBU Agricultural Development Authority), 8 entrepreneurs are members of MARA (Majlis Amanah Raya - Council of Trust for the Bumiputera), and 17 entrepreneurs are members of TEKUN (Tabung Ekonomi Nasional - National Entrepreneurial Group Economic Fund). Among the 125 respondents, 16 of them noted that their amount of unpaid loans was more than RM10, 000.

\section{Descriptive, Reliability, and Normality}

The Cronbach's Alpha values for opportunities recognition competencies, relationship competencies, conceptual competencies, organizing competencies, strategic competencies, entrepreneurial competency, supportive environment, human capital development, competitive advantage, and informal women microenterprise performances are more than 0.7, while for commitment competencies, it is above 0.6 (Hair, Hult, Ringle, \& Sarstedt, 2013). The Shapiro-Wilk's test ( $\mathrm{p}>$.05) explains the normality of data distribution. Based on Table 2 , the $p$-value for all the items is less than 0.05 , which means that data is not normally distributed. This leads to the use of the non-parametric Independent-Samples-Mann-Whitney test.

Table 2

Descriptive, Reliability, and Normality

\begin{tabular}{|l|c|c|c|c|c|}
\hline & N of Items & Mean & $\begin{array}{c}\text { Std. } \\
\text { Deviation }\end{array}$ & $\begin{array}{c}\text { Cronbach'ss } \\
\text { Alpha }\end{array}$ & $\begin{array}{c}\text { Shapiro-Wilk } \\
\text { Tests of } \\
\text { Normality } \\
(\boldsymbol{p} \text {-value) }\end{array}$ \\
\hline Opportunity Recog. Comp. & 4 & 4.1211 & 0.5939 & 0.808 & 0.000 \\
\hline Relationship Competencies & 5 & 4.1958 & 0.5627 & 0.827 & 0.000 \\
\hline Conceptual Competencies & 5 & 3.7806 & 0.6809 & 0.848 & 0.000 \\
\hline Organizing Competencies & 5 & 4.1521 & 0.5156 & 0.810 & 0.000 \\
\hline Strategic Competencies & 5 & 3.9667 & 0.5491 & 0.846 & 0.000 \\
\hline Commitment Competencies & 3 & 4.1467 & 0.5494 & 0.633 & 0.000 \\
\hline Entrepreneurial Competency & 5 & 4.0605 & 0.4022 & 0.787 & 0.000 \\
\hline Supportive Environment & 5 & 3.7026 & 0.7662 & 0.827 & 0.000 \\
\hline Human Capital Development & 5 & 3.9651 & 0.5764 & 0.727 & 0.000 \\
\hline Economic Vulnerability & 3 & 3.1664 & 0.7199 & N/A & 0.000 \\
\hline Competitive Advantage & 6 & 3.8693 & 0.54719 & 0.730 & 0.000 \\
\hline Inf. Micro-Enterprise Perf. & 6 & 3.9484 & 0.5171 & 0.751 & 0.000 \\
\hline
\end{tabular}

\section{Hypothesis Testing}

As shown in Table 3, the mean values for relationship competencies, conceptual competencies, organizing competencies, and overall entrepreneurial competency among the participant is relatively higher than that of non-participants. However, the $p$-value of Independent Samples-Mann-Whitney test for all items of entrepreneurial competencies is more than 0.05 ; therefore, the data do not allow us to conclude 
that participation in development organizations has a positive effect on the entrepreneurial competencies of the informal women micro-entrepreneurs in Kelantan, Malaysia.

Based on the findings of earlier studies, this study presumed that participation in group-based microcredit programs can lead to the development of social capital, which together may provide a platform for micro-entrepreneurs to learn and grow (Al Mamun, 2014; Mura \& Tavakoli, 2014). Moreover, the training provided by development organizations is expected to improve the entrepreneurial competencies among the participants. However, the findings of this study do not provide any clear indication of the effectiveness of the enterprise development training programs on entrepreneurial competencies and human capital development among the women informal micro-entrepreneurs in Kelantan, Malaysia, which contradicts recent findings of a study conducted by Manaf (2017) in a similar context.

The mean values for entrepreneurial performance among the participants are relatively higher than that of the non-participants (see Table 3). However, this study does not provide any indication of the existence of a positive effect among the population, which partially contradicts (there is a difference in the sampled respondents, however it is not statistically significant) most of the studies that have examined the effectiveness of development initiatives on micro-entrepreneurs (i.e., Panda, 2009; Rahman, Rafiq, \& Momen, 2009). However, this study highlights the positive and significant effects of participation in development programs in creating a supportive environment and competitive advantages among the lowincome informal women micro-entrepreneurs in Kelantan, Malaysia.

Table 3

Hypothesis Testing

\begin{tabular}{|l|c|c|c|c|c|}
\hline & \multicolumn{2}{|c|}{$\begin{array}{c}\text { Participants } \\
(\mathbf{n = 1 2 5})\end{array}$} & \multicolumn{2}{c|}{$\begin{array}{c}\text { Non-Participants } \\
(\mathbf{n = 2 5 9})\end{array}$} & $\begin{array}{c}\text { Mann- } \\
\text { Whitney } \\
(\boldsymbol{p} \text {-value })\end{array}$ \\
\hline & Mean & $\begin{array}{c}\text { Std. } \\
\text { Deviation }\end{array}$ & Mean & $\begin{array}{c}\text { Std. } \\
\text { Deviation }\end{array}$ & \\
\hline Opportunities Recognition Competencies & 4.1160 & 0.55134 & 4.1236 & 0.61449 & 0.678 \\
\hline Relationship Competencies & 4.2400 & 0.54299 & 4.1745 & 0.57179 & 0.227 \\
\hline Conceptual Competencies & 3.8520 & 0.65539 & 3.7461 & 0.69151 & 0.176 \\
\hline Organizing Competencies & 4.1664 & 0.51477 & 4.1452 & 0.51693 & 0.654 \\
\hline Strategic Competencies & 3.9216 & 0.64353 & 3.9884 & 0.49714 & 0.490 \\
\hline Commitment Competencies & 4.1307 & 0.57563 & 4.1544 & 0.53732 & 0.839 \\
\hline Entrepreneurial Competency & 4.0711 & 0.39118 & 4.0554 & 0.40809 & 0.758 \\
\hline Supportive Environment & 4.0640 & 0.57507 & 3.5282 & 0.78667 & 0.000 \\
\hline Human Capital Development & 4.0128 & 0.59609 & 3.9421 & 0.56641 & 0.173 \\
\hline Economic Vulnerability & 3.1182 & 0.64991 & 3.1896 & 0.75146 & 0.101 \\
\hline Competitive Advantage & 3.9600 & 0.58254 & 3.8255 & 0.52485 & 0.046 \\
\hline Informal Micro-Enterprise Performances & 3.9613 & 0.58473 & 3.9421 & 0.48232 & 0.495 \\
\hline
\end{tabular}

\section{DISCUSSION AND CONCLUSION}

Micro-enterprise development programs in Malaysia are focused on improving the socio-economic condition of low and middle-income households by encouraging entrepreneurial activities. This is timely given the contribution of entrepreneurship to reduce poverty, create employment, and develop the community and nation is well recognized. In order to encourage entrepreneurial activities among women informal micro-entrepreneurs, development organizations offer various development programs in the form of financial assistance, training, knowledge, and information. These development programs are determined and focused solely on improving and fostering micro-enterprises in Malaysia. The findings of this research 
suggest that participation in development programs leads to improvement in the area of access to supportive environments and competitive advantage. These improvements are expected to have a positive effect on micro-enterprise performance with the establishment of a proper supportive environment. In addition, it provides the participants with information, opportunities, experience and an idea-sharing platform, and increases their network size (formal and/or informal). Furthermore, the findings show that the microenterprise performance of participants is better compared to the non-participants. All the positive effects of development programs are ultimately expected to increase the performance of women microenterprises in the informal sector. This study however did not provide a clear evidence of the effectiveness of the enterprise development training programs offered by development organizations on entrepreneurial competencies and human capital development among the women informal micro-entrepreneurs in Kelantan, Malaysia. Future studies can focus on examining the effectiveness of enterprise development training programs, which can lead to a better understanding of the limitation of the current training programs and policies for promoting micro-entrepreneurial activities among the low-income and poor households in Malaysia. Apart from that, initiatives should be taken to spread the positive effects of the development programs by increasing the number of participants, which would lead to the improvement of social economic conditions, as well as the reduction of poverty among low and middle-income households in Malaysia.

\section{REFERENCES}

Abdullah, M. A., \& Manan, S. K. (2010). Adequacy of Financial Facilities for Small-Medium Businesses: Empirical Findings from Malaysia. International Review of Business Research Papers, 6(4), 535-548.

Achtenhagen, L., Melin, L., \& Naldi, L. (2013). Dynamics of Business Models Strategizing, Critical Capabilities and Activities for Sustained Value Creation. Long Range Planning, 46(6), 427-442.

Al Mamun, A. (2014). Investigating the Development and Effects of Social Capital through Participation in Groupbased Microcredit Program in Peninsular Malaysia. Journal of Interdisciplinary Economics, 26(1-2), 33-59.

Ahmad, N. H., Halim, H. A., \& Mohamed Zainal, S. R. (2010). Is Entrepreneurial Competency the Silver Bullet for SME Success in a Developing nation?, Interdisciplinary Journal of Contemporary Research in Business, 2(1), 217-236.

Autant-Bernard, C., Fadairo, M., \& Massard, N. (2013). Knowledge Diffusion and Innovation Policies within the European Regions: Challenges based on Recent Empirical Evidence. Research Policy, 42(1), 196-210.

Bae, J., \& Rowley, C. (2004). Macro and Micro Approaches in Human Resource Development: Context and Content in South Korea. Journal of World Business, 39(4), 349-361.

Barney, J. (1991). Firm resources and sustained competitive advantage. Journal of management, 17(1), 99-120.

Becker, B. E., Huselid, M. A., \& Ulrich, D. (2001). The HR Scorecard: Linking People, Strategy, and Performance. Brighton: Harvard Business Press.

Bertulfo, L. (2011). Women and the Informal Sector. AusAID. Retrieved from: https://dfat.gov.au/aid/how-wemeasure-performance/ode/Documents/women-informal-economy-lota-bertulfo.pdf (24th July, 2016)

Bhowmik, S. K. (2005). Street vendors in Asia: a review. Economic and political weekly, 2256-2264.

Bierly, P., \& Chakrabarti, A. (1996). Generic Knowledge Strategies in the U.S. Pharmaceutical Industry. Strategic Management Journal, 17(10), 123-135.

Borron, S., \& Murray, K. (2004). Bridging the Unsustainability Gap, a Framework for Sustainable Development. Sustainable Development, 12(2), 65-73.

Brush, M. C., \& Ruse, D. H. (2005). Driving Strategic Success Through Human Capital Planning: How Corning Links Business and HR Strategy to Improve The Value and Impact of Its HR Function. Human Resource Planning, 28(1), 49-61.

Bull, I., \& Willard, G. E. (1993). Towards a Theory of Entrepreneurship. Journal of Business Venturing, 8(3), 183-195.

Camuffo, A., Gerli, F., \& Gubitta, P. (2012). Competencies Matter: Modeling Effective Entrepreneurship in Northeast of Italy Small Firms: Cross Cultural Management. International Journal, 19(1), 48-66. 
Carmeli, A., \& Tishler, A. (2004). The Relationships between Intangible Organizational Elements and Organizational Performance. Strategic Management Journal, 25, 1257-1278.

Chandler, G. N., \& Jansen, E. (1992). The Founder's Self-Assessed Competence and Venture Performance. Journal of Business Venturing, 7(3), 223-236.

Cooper, A. C. (1993). Challenges in Predicting New Firm Performance. Journal of Business Venturing, 8(3), 241-253.

Covin, J. G., \& Slevin, D. P. (1991). A Conceptual Model of Entrepreneurship as Firm Behavior. Entrepreneurship: Theory \& Practice, 16(l), 7-25.

D'Aveni, R., Dagnino, G., \& Smith, K. (2010). The age of temporary advantage. Strategic Management Journal, 31(13), 1371-1385. doi:http://dx.doi.org/10.1002/smj.897

Dencker, J. C., Gruber, M., \& Shah, S. K. (2009). Pre-Entry Knowledge, Learning, and the Survival of New Firms. Organization Science, 20(3), 516-537.

Donatus, O. (2010). Entrepreneurial Orientation and Psychological Traits: the Moderating Influence of Supportive Environment. Journal of Behavioral Studies in Business, 3(1). 1-16.

Eyre, P., \& Smallman, C. (1998). Euro-Management Competencies in Small and Medium Sized Enterprises: A Development Path for the New Millennium?, Management Decision, 36(1), 34-42.

Fairlie, R. W., \& Robb, A. (2009). Why a Black-Owned Business Less Successful Than White-Owned Business? The Role of Families, Inheritances and Business Human Capital. Journal of Labor Economics, 25(2), 289-323.

Floro, M., \& Swain, R. (2013). Food Security, Gender, and Occupational Choice among Urban Low-Income Households. World Development, 42, 89-99.

Fussel, H. M. (2007). Adaptation Planning for Climate Change: Concepts, Assessment Approaches, and Key Lessons. Sustainability Science, 2(2), 265-275.

Gentry, W., \& Hubbard, R. (2004). Entrepreneurship and Household Saving. Advances in Economic Analysis and Policy, 4(1), 1-55.

Gibbs, R. (2005). Education as a Rural Development Strategy. Amber Waves, 3(5), 20-25.

Habibullah, M.Z., \& Eng, Y.K. (2006). Does financial development cause economic growth? a panel data dynamic analysis for Asian developing countries. Journal of the Asian Pacific Economy, 11(4), 377-393.

Hafizah, S., Ratna Roshida, A. R., Salfarina, A. G., \& Zainal Abidin, S. (2011). Survival through Entrepreneurship: Determinants of Successful Micro-Enterprise in Balik Pulau, Penang Island, Malaysia. British Journal of Arts and Social Sciences, 3(1), 23-37.

Hair Jr, J. F., Hult, G. T. M., Ringle, C., \& Sarstedt, M. (2013). A Primer on Partial Least Squares Structural Equation Modeling (PLS-SEM). Sage Publications.

Hana, U. (2013). Competitive Advantage Achievement through Innovation and Knowledge. Journal of Competitiveness, 5(1), 82-96.

Hawawini, G., Subramanian, V., \& Verdin. P. (2003). Is Performance Driven by Industry or Firm-Specific Factors? A New Look at the Evidence. Strategic Management Journal, 24(1), 1-16.

Hebert, R. F., \& Link, A. N. (1989). In Search of the Meaning of Entrepreneurship. Small Business Economics, 1(1), 3949.

Hee, S. N., \& Daisy, M. H. K. (2013). Effect of Entrepreneurial Competencies on Firm Performance under the Influence of Organizational Culture. Life Science Journal, 10(4), 2459-2466.

Helfat, C. E., \& Peteraf, M. A. (2015). Managerial Cognitive Capabilities and the Microfoundations of Dynamic Capabilities. Strategic Management Journal, 36(6), 831-850.

Hicks, R. (2012). The Capability Approach: Insights for a new Poverty Focus. Journal of Social Policy, 41, 291-308.

Hitt, M. A., Bierman, L., Uhlenbruck, K., \& Shimizu, K. (2006). The Importance of Resources in the Internationalization of Professional Service Firms: The Good, the Bad, and the Ugly. Academy of Management Journal, 49(6), 1137-1157.

Hunter, M. (2011). Perpetual Self-Conflict: Self-Awareness as a Key to our Ethical Drive, Personal Mastery and Perception of Entrepreneurial Opportunities. Contemporary Readings in Law and Social Justice, 3(2), 96-137.

Hussain, D., \& Zafar, Y. (2010). Micro-entrepreneurs: Motivations, Challenges and Success Factors, International Research Journal of Finance and Economics, 56, 22-28. 
Jawahar, D., \& Nigama, K. (2011). The Influence of Social Capital on Entrepreneurial Opportunity Recognition Behavior. International Journal of Economics and Management, 5(1), 351-368.

Kaur, H., \& Bains, A. (2013). Understanding the Concept of Entrepreneur Competency. Journal of Business Management \& Social Sciences Research, 2(11), 31-33.

Kozan, M. K., Oksoy, D., \& Ozsoy, O. (2012). Owner Sacrifice and Small Business Growth. Journal of World Business, 47(3), 409-419.

Kuchairi, A. A., \& Nur Layali, M. A. K. (2015). Regional Course on Statistics on Informality: Informal Economy, Work and Employment. Country Report for Malaysia. Available from: http://www.unsiap.or.jp/elearning/2 population/1507 Informal.html (23.04.2016)

Kraus, S., Rigtering, J. C., Hughes, M., \& Hosman, V. (2012). Entrepreneurial Orientation and The Business Performance of SMEs: A Quantitative Study from The Netherlands. Review of Managerial Science, 6(2), 161-182.

Kweka, J., \& Fox, L. (2011). The Household Enterprise Sector in Tanzania. Why it Matters and Who Cares. Policy Research Working Paper. The World Bank African Region.

Lehrer, E. (2004). Religiosity as a Determinant of Educational Attainment: The Case of Conservative Protestant Women in the United States. Review of Economics of the Household, 2(2), 203-219.

Lloyd-Evans, S. (2008). Geographies of the Contemporary Informal Sector in the Global South: Gender, Employment Relationships and social Protection. Geography Compass, 2(6), 1885-906.

Lockett, A., \& Thompson, S. (2001). The resource-based view and economics. Journal of management, 27(6), 723-754.

Mahmood, R., \& Mohd Rosli, M. (2013). Microcredit position in micro and small enterprise performance: the Malaysian case. Management research review, 36(5), 436-453.

Man, T. W., \& Lau, T. (2000). Entrepreneurial Competencies of SME Owner/Managers in the Hong Kong Services Sector: A Qualitative Analysis. Journal of Enterprising Culture, 8(3), 235-254.

Man, T. W. Y., Lau, T., \& Chan, K. F. (2002). The Competitiveness of Small and Medium Enterprises: A Conceptualization with Focus on Entrepreneurial Competencies. Journal of Business Venturing, 17(2), 123-142.

Martín-de Castro, G., Delgado-Verde, M., Navas-López, J. E., \& Cruz-González, J. (2013). The Moderating Role of Innovation Culture in the Relationship between Knowledge Assets and Product Innovation. Technological Forecasting and Social Change, 80(2), 351-363.

Mapp, T. \& Moore, W. (2015). The informal economy and economic volatility. Macroeconomics and Finance in Emerging Market Economies, 8(1-2), 185-200.

Manaf, H. A. (2017). Impact of Microcredit Scheme on the Development of Entrepreneurship Skills among Low Income Households in a Developing Country Context. International Journal of Economics and Financial Issues, 7(1), 583-593.

McClelland, D. C. (1987). Characteristics of Successful Entrepreneurs. Journal of Creative Behavior, 21(3), 219-233.

McPherson, M. A. (1996). Growth of Micro and Small Enterprises in Southern African. Journal of Development Economics, $48(2), 253-277$.

Mead, D. C., \& Liedholm, C. (1998). The Dynamics of Micro and Small Enterprises in Developing Countries. World Development, 26(1), 61-74.

Mlinga, R. S., \& Wells, J. (2002). Collaboration between Informal and Formal Enterprises in the Construction Sector in Tanzania. Habitat International, 26, 269-280.

Monroe, S., Allen, K., \& Price, C. (1996). The Impact Of Entrepreneurial Training Programs on Transitioning Workers: The Public Policy Implications. Frontiers of Entrepreneurship Research. Babson Kauffman Research Conference Proceedings. Retrieved from https:/ fusionmx.babson.edu/entrep/fer/papers95/monroe.htm

Moser, C. (1998). The Asset Vulnerability Framework: Reassessing Urban Poverty Reduction Strategies. World Development, 26(1), 1-19.

Mura, P., \& Tavakoli, R. (2014). Tourism and social capital in Malaysia. Current Issues in Tourism, 17(1), $28-45$.

Nirathron, N. (2006). Fighting Poverty from the Street A Survey of Street Food Vendors in Bangkok. Bangkok: International Labour Office.

Noruzy, A., Dalfard, V. M., Azhdari, B., Nazari-Shirkouhi, S., \& Rezazadeh, A. (2012). Relations between Transformational Leadership, Organizational Leasing, Knowledge Management, Organizational Innovation and 
Organizational Performance: An Empiric Investigation of Manufacturing Firms. International Journal of Advanced Manufacturing Technology, 64(5-8), 1073-1085.

Nurach, P., Thawesaengskulthai, D., \& Chandrachai, A. (2012). Developing an Organization Competencies Framework for SME(s) in Thailand. Chinese Business Review, 11(2), 233-241.

Okurut, F.N. (2008). Determinants of Microenterprise Performance in Uganda. ICF AI Journal of Agricultural Economics, 5(1), 77-87.

Olssen, M., Codd, J., \& O'Neill, A. (2004). Education policy: globalization, citizenship and democracy (1st ed.). London: Sage Publ.

Pages, E. (2005). The Changing Demography of Entrepreneurship. Local Economy, 20(1), 93-97.

Panda K. D. (2009), Participation in the Group Based Microfinance and its Impact on Rural Households: A Quasiexperimental Evidence from an Indian State, Global Journal of Finance and Management, 1(2), 171-183.

Parast, M., \& Adams, S. (2012). Corporate Social Responsibility, Benchmarking, and Organizational Performance in the Petroleum Industry: A Quality Management Perspective. International Journal of Production Economics, 139(2), 447-458.

Parkman, I., Holloway, S., \& Sebastiao, H. (2012). Creative Industries: Aligning Entrepreneurial Orientation and Innovation Capacity. Journal of Research in Marketing and Entrepreneurship, 14(1), 95-114.

Ployhart, R., Weekley, J., \& Baughman, K. (2006). The Structure and Function of Human Capital Emergence: A Multilevel Examination of the ASA model. Academy of Management Journal, 49(4), 661-677.

Porter, M. E. (1985). Competitive Advantage. New York: Free Press.

Putnam, R. (1993). The Prosperous Community: Social Capital and Public Life. American Prospect, 13, 35-42.

Rahman, S., Rafiq, R. B. and Momen, M. A. (2009). Impact of Microcredit Programs on Higher Income Borrowers: Evidence from Bangladesh. International Business \& Economics Research Journal, 8(2), 119-124.

Rosa, P., Carter, S., \& Hamilton, D. (1996). Gender as a Determinant of Small Business Performance: Insights from a British Study. Small Business Economics, 8(6), 463-478.

Sambasivan, M., Lim, L. Y., Rose, R. C., \& Abdul, M. (2010). Venture Performance in Malaysia: Personal Initiative, Human Capital, and Competency Areas of Founding Entrepreneurs as Critical Success Factors. Journal of Small Business \& Entrepreneurship, 23(3), 315-332.

Schaltegger, S., Freund, F., \& Hansen, E. (2012). Business Cases for Sustainability: The Role of Business Model Innovation for Corporate Sustainability. International Journal of Innovation and Sustainable Development, 6(2), 95-119.

Schmidt, M., \& Kolodinsky, J. (2007). Microenterprise Development Program Success: a Path Analysis of Factors that Lead to and Mediate Client Success. Journal of Developmental Entrepreneurship, 12(1), 47-69.

Seo, J. (2005). Overcoming Economic Hardship: The Effects Of Human Capital And Social Capital (Ph.D). The Ohio State University.

Servon, L., \& Doshna, J. (2000). Microenterprise and Economic Development Toolkit: a Small Part of the Big Picture. Journal of Developmental Entrepreneurship, 5(3), 183-208.

Sharma, A., Sapna, D., \& Hatwal, V. (2012). Microenterprise Development and Rural Women Entrepreneurship: Way for Economic Empowerment. Journal of Economics and Management, 1(6), 114-127.

Shenura,, S., Haile, A., \& Negash, E. (2016). Prospects of Entrepreneurial Competencies of Micro and Small Enterprise in Jimma Zone, Ethiopia. Global Journal Of Management And Business Research: B Economics And Commerce, 16(2), 1830.

Simpson, M., Padmore, J., \& Newman, N. (2012). Towards a New Model of Success and Performance in SMEs. International Journal of Entrepreneurial Behavior \&o Research, 18(3), 264-285.

Simsek, Z. \& Heavey, C. (2011). The Mediating Role of Knowledge-Based Capital for Corporate Entrepreneurship Effects On Performance: A Study of Small-to Medium-Sized Firms. Strategic Entrepreneurship Journal, 5(1), 81-100.

Siqueira, A. (2007). Entrepreneurship and Ethnicity: The Role of Human Capital and Family Social Capital. Journal of Developmental Entrepreneurship, 12(1), 31-46.

Skrzeszewski, S. (2006). Knowledge Entrepreneur. Scarecrow Press.

Snell, R., \& Lau, A. (1994). Exploring Local Competences Salient for Expanding Small Businesses. Journal of Management Development, 13(4), 4-15.

Snell, S. (1999). Social Capital and Strategic HRM: It's Who You Know. Human Resource Planning, 22(1), 62-65. 
Sparrow, R., Poel, E., Hadiwidjaja, G., Yumna, A., Warda, N., \& Suryahadi, A. (2014). Coping with the Economic Consequences of Ill Health in Indonesia. Health Economics, 23(6), 719-728.

Spevaek, A. (2011). Promoting Female Sustainable Livelihoods (Employment and Entrepreneurship) in the Europe and Russia (E \& E) Region. Usaid Knowledge Services Center (KSC), United States.

Sullivan, D., \& Marvel, M. (2011). Knowledge Acquisition, Network Reliance, and Early-Stage Technology Venture Outcomes. Journal of Management Studies, 48(6), 1169-1193.

Sverke, M., Hellgren, J., \& Näsvall, K. (2006). Job Insecurity: A literature review. Stockholm: National Institute for Working Life (Sweden). Retrieved March 2, 2017, from http://nile.lub.lu.se/arbarch/saltsa/2006/wlr2006 01.pdf.

Thompson, J., Stuart, R., \& Lindsay, P. (1996). The Competence of Top Team Members: A Framework for Successful Performance. Journal of Managerial Psychology, 11(3), 48-66.

Tidd, J., Bessant, J., \& Pavitt, K. (2006). Řiz̨eni Inovaci - Zavádèní Technologicky $\square$ Ch, Tržnich A Organizačnich Zmèn. Brno: Computer Press.

Tipple, G. (2005). The Place of Home-Based Enterprises in the Informal Sector: Evidence from Cochabamba, New Delhi, Surabaya and Pretoria. Urban Studies, 42(4), 611-632.

Tuyon, J., Bujang, I., \& Jidwin, A. (2012). Government's Financial and Business Development Support for Microenterprises in Malaysia: Controversies and Policy Perspectives. Journal of Asia Entrepreneurship and Sustainability, 8(1), 48-80.

UNDP (2014). Study to support the development of national policies and programs to increase and retain the participation of women in the Malaysian labor force: key finding and recommendation. Retrieved from: http://www.my.undp.org/content/malaysia/en/home/library/womens empowerment/women-in-malaysianlabour-force-study-with-undp-2013.html.

Verrest, H. (2013). Rethinking Micro-Entrepreneurship and Business Development Programs: Vulnerability and Ambition in Low-Income Urban Caribbean Households. World Development, 47(1), 58-70.

Vial, V., \& Hanoteau, J. (2015). Returns to Micro-Entrepreneurship in an Emerging Economy: A Quantile Study of Entrepreneurial Indonesian Households' Welfare. World Development, 74, 142-157.

Wells, B., Pfantz, T., \& Bryne, J. (2003). Russian Women Business Owners: Evidence of Entrepreneurship in A Transition Economy. Journal of Developmental Entrepreneurship, 8(1), 59-71.

Williams, C., \& Windebank, J. (2006). Harnessing the Hidden Enterprise Culture of Advanced Economies. International Journal of Manpower, 27(6), 535-551.

Xiao, J. (2002). Determinants of salary growth in Shenzhen, China: an analysis of formal education, on-the-job training, and adult education with a three-level model. Economics of Education Review, 21(6), 557-577.

Yusuf, A. (1995). Critical Success Factors for Small Business: Perceptions of South Pacific Entrepreneurs. Journal of Small Business Management, 33(2), 68-73.

Zack, M. H. (1999). Developing a Knowledge Strategy. California Management Review, 41(3), 125-145.

Zahra, S. A., \& Nambisan, S. (2012). Entrepreneurship and Strategic Thinking in Business Ecosystem. Business Horizons, $55,219-229$.

Zemplinerová, A. (2010). Inovační Aktivita Firem a Konkurence. Politická Ekonomie, 58(6), 747-760.

Zikmund, W. G. (2003). Business Research Methods, (7th edn). Thompson South-Western: Ohio. 